\title{
Factors Affecting Bank Risk-Taking: Evidence from Southeast Asian Countries
}

\author{
TRAN HUNG SON \\ University of Economics and Law - sonth@uel.edu.vn \\ NGUYEN THANH LIEM \\ University of Economics and Law - liemnt@uel.edu.vn \\ HOANG TRUNG NGHIA \\ University of Economics and Law - nghiaht@uel.edu.vn
}

\begin{abstract}
ARTICLE INFO
ABSTRACT

Article history:

In this paper we use a dynamic panel data model (system GMM

Received:

Apr. 92015 estimator) to analyze bank-specific and macroeconomic determinants of bank risk as measured by the Z-score of 70 listed commercial banks Received in revised form:

Aug. 112015 operating in six Southeast Asian countries over the period from 2005 to 2013. Our results indicate that asset structure, capitalization, size, and the stock market development are negatively and significantly related to bank risk, which is, in turn, positively related to efficiency, revenue diversification, and the banking system development.

Accepted:
\end{abstract}

Mar. 252016

Keywords:

Bank risk, Z-score,

Southeast Asian countries, banking system 


\section{Introduction}

On the international scene, conducting banking business has become ever riskier, as well as the actions by monetary authorities that are more onerous than ever before. Bank risk is an issue that has had its importance re-emphasized by the banking crisis of 2008 . This is understandable because of the negative experiences and particularly serious, negative repercussions of the banking crisis on individual national economies. As banks play a dominant role in most of the financial system as the main source of financing and payment management system, financial collapse can have serious macro-economic consequences on the national economy.

Literature identifies various determinants of bank risk, including bank-specific variables and macroeconomic variables (Louzis et al., 2012; Poghosyan \& Čihak, 2011; Baselga-Pascual et al., 2015; Vithessonthi, 2014), the effects of both of which are to be investigated in this paper on risk of commercial banks in six Southeast Asian countries in the context of the recent global financial crisis. The paper is structured as follows. Section 2 describes the literature on bank risk. Section 3 presents the data and methodology employed in the empirical research and defines explanatory variables. The results obtained are presented and discussed in Section 4, followed by Section 5, which summarizes the findings and also draws several conclusions and implications.

\section{Literature review}

According to the literature, the factors that influence bank risk fall into two main groups. First, there is a group of determinants of risk that are specific to each bank, and that, in many cases, are the direct result of managerial decisions. These include asset structure, capitalization, profitability, efficiency, and size. The second group of determinants comprises those relating bank risk to the industry structure and to the macroeconomic environment within which the banking system operates, such as economic growth, inflation, and financial development.

Ruiz-Porras (2009) inspected the effect of financial structure and financial development on banking fragility for a sample of 211 countries in the period of 1990 2008. He found that banking stability increases in countries with the market-based financial system while financial development reduces it. Nevertheless, the fragilityenhancing effect can only be observed when financial structure is taken into account. Therefore, both financial structure and financial development affect banking fragility. 
Vithessonthi (2014) studied the influence of financial development on risk of 52 banks (measured by bank capital and revenue diversification) in five South East Asian countries during the period between 1990 and 2012. His empirical results indicated that financial development tends to increase bank risk; in particular, the financial development is negatively related to bank capital in the period after the Asian financial crisis, and positively related to bank revenue diversification. The study also found a Ushaped (non-linear) development-capital relationship.

In a similar study Baselga-Pascual et al. (2015) analyzed how bank-specific and macroeconomic determinants affect bank risk in Europe between 2005 and 2011. Their findings show that capital, profitability, efficiency, and liquidity decrease bank risk. Moreover, less competitive markets, lower interest rate, and economic recession (with falling GDP) are positively related to bank risk.

Cubillas and González (2014) examined the influence of financial liberalization on risk of 4,333 banks in 83 countries. They found that financial sector liberalization increases bank risk-taking in both developed and developing countries yet via different channels. For developed countries financial liberalization enhances bank competition, thereby causing a rise in bank risk. On the other hand, it expands opportunities for banks in other developing countries to engage in risky activities. Capital requirements serve to mitigate the adverse effect of financial liberalization on financial stability in both types of countries. However, regulations on official supervision and financial transparency are only valid in developing countries, whereas in developed countries regulations on bank risk-taking are found to be ineffective due to higher levels of bank competition.

Louzis et al. (2012) attempted to identify the bank-specific determinants of nonperforming loans (NPLs) across various loan categories, including consumer loans, business loans, and mortgages in the Greek banking sector. They also detected the role of macroeconomic determinants (i.e. GDP, unemployment rates, interest rates, and public debt) and management quality in explaining NPLs, and concluded that there exists a marked difference in quantitative impact of the macro factors on NPLs and other types of loans.

Addressing the role of national governance upon bank-level risk in the Asian region, Williams (2014) demonstrated that improvements in national governance lead to risk reduction at the bank level in Asian developed countries, and also for those influenced by the Asian Financial Crisis in the longer run. A U-shaped relationship was detected 
between bank risk and bank capital, and only for developed nations is the risk-reducing effect of rising capital holdings suggested to be reaching satiation. Additionally, more evidence was shown on risk seeking behavior on account of the 'too big to fail' impact besides improvements in national governance in developed nations. Higher risk posed to banks in developing countries was associated with larger size coupled with better national governance practices.

\section{Data and methodology}

\subsection{Data}

We assemble unbalanced annual panel data of different Southeast Asian banks and countries for the period of 2005-2013 based on Datastream and World Development Indicators (WDI) by World Bank. The listed commercial banks are from six Southeast Asian countries, including Indonesia, Malaysia, the Philippines, Singapore, Thailand, and Vietnam. The final sample covers a total of 70 listed commercial banks, with 675 bank-year observations.

Table 1 presents summary statistics of the banks and macroeconomic data. An average Z-score ratio is 31.758 , while average leverage risk (Levrisk) and averarge portfolio risk (Portrisk) are 29.361 and 4.219 respectively ${ }^{1}$.

\section{Table 1}

Summary statistics for Southeast Asian commercial banks

\begin{tabular}{lccccc}
\hline \multicolumn{1}{c}{ Variable } & Obs. & Mean & Std. Dev. & Min & Max \\
\hline Z-score & 523 & 31.758 & 24.312 & -13.380 & 197.578 \\
Levrisk & 575 & 29.361 & 29.551 & -12.238 & 386.454 \\
Portrisk & 523 & 4.219 & 3.471 & -2.826 & 19.983 \\
Asset & 566 & 0.674 & 0.141 & 0.222 & 0.979 \\
CIR & 574 & 6.363 & 53.730 & -826.966 & 665.552 \\
Equity & 575 & 0.096 & 0.183 & -2.978 & 0.890 \\
RD & 565 & 0.191 & 0.112 & -0.406 & 0.675 \\
Size & 575 & 21.052 & 2.955 & 10.695 & 27.315 \\
GDP & 630 & 5.276 & 2.178 & -2.330 & 15.240
\end{tabular}




\begin{tabular}{lccccc}
\hline \multicolumn{1}{c}{ Variable } & Obs. & Mean & Std. Dev. & Min & Max \\
\hline ROE & 548 & 0.095 & 0.374 & -6.503 & 1.842 \\
INF & 630 & 5.331 & 3.149 & -0.850 & 23.120 \\
BSD & 630 & 58.409 & 40.940 & 24.610 & 154.400 \\
SMD & 560 & 67.790 & 43.805 & 0.800 & 248.519 \\
\hline
\end{tabular}

Sources: Thomson Reuters Datastream (2015), World Bank (2015), and authors' calculations

Table 2 provides the mean value for bank characteristics and macro-economic variables by country. There are great differences among the banks in the area. For the ratio of loan to assets, banks in Philippines and Thailand reveal the lowest ratios while those of Vietnam and Singapore are the highest. Efficiency of Vietnamese and Indonesian banks is not as high as that of banks in the Philippines and Thailand in terms of the ratio of cost to operating income. As for the ratio of equity to total assets, Vietnamese banks are ranked worst, and their business is also quite risky, whereas banks in Indonesia and Singapore have high ratios of equity capital to total assets. The profitability is quite similar among the countries in the area as most reflect the ROE of 9-11\%, except for that of Vietnamese banks, which is around $13.9 \%$ (highest), and of Singaporean ones, only $4.8 \%$ (perhaps indicating the risk level in each country). In terms of Z-score, interestingly, the most risky banking business is recorded with those in Singapore and the Philippines, while Thailand and Malaysia witness the most stable performance of their banks. For financial development variables, both banking and stock markets seem to be the most thriving in Malaysia, Singapore, and Thailand, whereas Vietnam's banks tend to dominate its stock market, and the observation is opposite for the banks in Indonesia and the Philippines. Furthermore, Vietnam and Indonesia have the highest inflation rates and growth rates also.

Pair-wise correlation coefficients and variance inflation factor (VIF) for the variables are to be calculated and reported in Tables 3 and 4 . All the variables satisfy the test of multicollinearity $(<4)^{2}$. 


\section{Table 2}

Summary statistics by country

\begin{tabular}{lccccccccc}
\hline Country & Asset & CIR & Equity & ROE & Z-Score & CPI & GDP & BSD & SMD \\
\hline Indonesia & 0.703 & 9.560 & 0.121 & 0.090 & 31.726 & 0.073 & 0.059 & 0.296 & 0.388 \\
Malaysia & 0.703 & 6.247 & 0.074 & 0.119 & 39.452 & 0.026 & 0.048 & 1.093 & 1.381 \\
Philippines & 0.502 & 2.185 & 0.070 & 0.114 & 28.363 & 0.047 & 0.052 & 0.306 & 0.625 \\
Singapore & 0.805 & 4.864 & 0.091 & 0.048 & 25.286 & 0.031 & 0.036 & 1.228 & 0.722 \\
Thailand & 0.593 & 2.048 & 0.087 & 0.120 & 43.685 & 0.028 & 0.060 & 1.005 & 1.626 \\
Vietnam & 0.741 & 10.153 & 0.060 & 0.139 & 32.932 & 0.108 & 0.062 & 0.895 & 0.152 \\
\hline
\end{tabular}

Source: authors' calculations

\section{Table 3}

Correlation matrix

\begin{tabular}{|c|c|c|c|c|c|c|c|c|c|c|c|}
\hline & Z-score & Portrisk & Levrisk & $\mathrm{RD}$ & Asset & CIR & Equity & Size & ROE & GDP & INF BSD SMD \\
\hline Z-score & 1.00 & & & & & & & & & & \\
\hline Portrisk & 0.75 & 1.00 & & & & & & & & & \\
\hline Levrisk & 0.99 & 0.68 & 1.00 & & & & & & & & \\
\hline RD & 0.01 & 0.12 & -0.02 & 1.00 & & & & & & & \\
\hline Asset & -0.01 & 0.03 & 0.02 & -0.17 & 1.00 & & & & & & \\
\hline CIR & -0.03 & -0.03 & -0.03 & -0.06 & 0.00 & 1.00 & & & & & \\
\hline Equity & 0.20 & 0.10 & 0.25 & -0.12 & 0.01 & 0.00 & 1.00 & & & & \\
\hline Size & 0.05 & 0.13 & -0.04 & -0.44 & 0.23 & 0.00 & 0.19 & 1.00 & & & \\
\hline ROE & 0.13 & 0.26 & 0.10 & 0.18 & -0.01 & 0.00 & 0.13 & 0.11 & 1.00 & & \\
\hline GDP & 0.07 & 0.04 & 0.05 & -0.11 & -0.09 & 0.01 & 0.00 & 0.17 & 0.02 & 1.00 & \\
\hline INF & -0.10 & -0.12 & -0.09 & -0.52 & -0.11 & 0.02 & 0.05 & 0.47 & 0.01 & 0.18 & 1.00 \\
\hline BSD & 0.05 & 0.12 & 0.05 & 0.42 & 0.37 & -0.03 & -0.05 & -0.38 & 0.00 & -0.30 & $-0.53 \quad 1.00$ \\
\hline SMD & 0.17 & 0.19 & 0.15 & 0.49 & -0.01 & -0.06 & -0.11 & -0.53 & 0.04 & 0.10 & $\begin{array}{lll}-0.64 & 0.65 & 1.00\end{array}$ \\
\hline
\end{tabular}

Source: authors' calculations 


\section{Table 4}

Variance Inflation Factor (VIF) for the variables

\begin{tabular}{lll}
\hline Variable & VIF & $1 /$ VIF \\
\hline SMD & 3.59 & 0.28 \\
BSD & 3.53 & 0.28 \\
INF & 2.31 & 0.43 \\
Size & 2.14 & 0.47 \\
Asset & 2.00 & 0.50 \\
RD & 1.84 & 0.54 \\
GDP & 1.46 & 0.68 \\
Equity & 1.25 & 0.80 \\
ROE & 1.08 & 0.93 \\
CIR & 1.03 & 0.98 \\
\hline
\end{tabular}

Source: authors' calculations

\subsection{Methodology}

In this paper we employ the system-GMM estimator suggested by Arellano and Bover (1995) and Blundell and Bond (1998) with Windmeijer's finite sample correction to rectify the severely downward biased standard errors in the two-step GMM (Windmeijer, 2005). We specify two types of instrumental variables for the systemGMM approach, including: (i) strictly exogenous regressors to be entered with IV-style option; and (ii) predetermined or suspected endogenous regressors to be entered with GMM-style option under xtabond2 command in Stata. The variables for the former are year and country dummies, whereas the instruments for the latter are Z-score, asset, and equity, concerning which we only use lag of two and three times to keep the number of instruments as small as possible. These two bank characteristics are suspected to be subject to the impact of bank risk-taking.

Initially, we estimate the following regression model:

$$
\begin{aligned}
& \text { Bankrisk }_{i, t}=+ \text { SBankrisk }_{i, t-1}+\beta_{1}\left(\text { Asset }_{i t}+\beta_{2}(\text { CIR })_{i t}+\beta_{3}(E Q U I T Y)_{i t}+\right. \\
& \beta_{4}(R D)_{i t}+\beta_{5}(\text { Size })_{i t}+\beta_{6}(R O E)_{i t}+\beta_{7}(G D P)_{i t}+\beta_{8}(I N F)_{i t}+\beta_{9}(B S D)_{i t}+ \\
& \beta_{10}(S M D)_{i t}+\varepsilon_{i t}
\end{aligned}
$$


We follow the literature to measure bank risk, using the Z-score (Laeven \& Levine, 2009; Demirgüc-Kunt \& Huizinga, 2010; Altunbas et al., 2011). Bank risk is accordingly calculated as below:

$$
Z-\text { score }_{i t}=\frac{R O A_{i t}+E Q T A_{i t}}{S_{R O A_{i}}}
$$

where EQTA is the ratio of equity capital to total assets of bank $i$ in year $t$ ) and $S_{R O A_{i}}$ is the standard deviation of the return on assets over the period between 2005 and 2013.

A higher Z-score indicates that bank performance is more stable because it is inversely related to the bank's insolvency probability. Because the Z-score is highly skewed, we use its natural logarithm, which is normally distributed. As alternative indicators of bank risk, we later also consider the two components of the Z-score, which measure banks' exposure to portfolio risk and leverage risk (Kohler, 2012).

We now turn the independent variables used in the regression analysis to bank risktaking:

Asset structure (Asset)

To estimate the impact of asset structure on bank risk, we employ the ratio of loan to total assets (Männasoo \& Mayes, 2009). Many studies have found that this ratio is positively related to bank problems, increasing NPLs and insolvency (Baselgael al., 2013; Männasoo \& Mayes, 2009); therefore, banks with high loan-to-asset ratios may have low Z-scrore levels (i.e. high risk). We hypothesize this nexus as follows:

H1: There is a positive relationship between the relative percentage of loans in the assets of a bank and its risk.

Efficiency (CIR)

Previous studies asserted that inefficiency is the bank risk source. We use the ratio of operating cost to operating income to measure the efficiency or managerial quality of banks (Männasoo \& Mayes, 2009). In their "bad management" hypothesis, Louzis et al. (2012) found that low cost efficiency has a positive correlation with the increase of NPLs in the future due to poor skills in credit scoring, appraisals of collaterals, and monitoring borrowers. Our second hypothesis is therefore the following:

H2: There is a negative correlation between bank efficiency and bank risk.

Capitalization (Equity) 
The equity-to-asset ratio is used to estimate capitalization. According to the traditional theory on risk, the higher the equity that a bank owns, the safer it is. The study of Poghosyan and Čihak (2011) found that a negative relation exists between this ratio and bank risk.

H3: There is a negative relation between capitalization and bank risk.

Revenue diversification $(R D)$

There is plenty of literature about how diversification influences bank risk. Many authors supported the idea that diversification does not reduce bank risk, but in fact may encourage it. Stiroh (2002) found that a greater reliance on non-interest income by US banks, particularly on trading revenue, could be associated with higher risk and lower risk-adjusted profits at the individual bank level during the period from the late 1970s to 2001. Demirgüc-Kunt and Huizinga (2010) concluded that although expansion into non-interest income-generating activities such as trading could offer some risk diversification benefits, banking strategies that rely prominently on generating noninterest income are very risky.

H4: There is a positive relation between revenue diversification and bank risk.

Bank size (Size)

Many studies suggested that large banks may have lower risk because of their managerial capacity and efficiency. In addition, large banks presumably implement strategies to diversify their activities, hence facing lower risk (Baselga-Pascual et al., 2015). Thus, we we expect a negative relationship between the size of the bank and its risk:

H5: There is a negative relationship between bank size and bank risk.

Profitability (ROE)

A great deal of research provides an empirical evidence for the negative relation between profitability, which is measured by return on equity (ROE), and bank risk. Poghosyan and Čihak (2011) argued that European banks that have good earnings are less likely to encounter financial problems in the coming year. Louzis et al. (2012) concluded that bad performance may be a proxy for bad management of lending activities, which leads to NPLs. Based on these findings, a negative relationship is anticipated between bank profitability and risk.

H6: There is a negative relationship between profitability and bank risk. 


\section{Economic development (GDP)}

Most researchers agreed that bank risk is cyclical, i.e. when the economy is growing with a stable macroeconomic environment, the bank system is also stable (Pophosyan \& Cihak, 2011). Since the findings of Baselga et al. (2013) indicated that economic growth is negatively related to bank risk, we expect a similar negative association between the two factors.

H7: There is a negative relation between economic growth and bank risk.

\section{Inflation (INF)}

The study of Baselgaet al. (2013) showed a positive relation between inflation and bank risk. Uhde and Heimeshoff (2009) stated that the impact of inflation is dependent on whether the bank can forecast inflation and fragility of the economy; nevertheless, their empirical evidence, using an EU-25 sample, shows a direct effect on bank risk as measured by the Z-score. Therefore, inflation rates are expected to be positively associated with bank risk.

H8: There is a positive relation between inflation and bank risk.

Bank sector development (BSD)

The development of bank sector is measured by the ratio of domestic credit provided by the banking sector to GDP. Köhle (2012) concluded that when the growth of credit to private sector exceeds GDP growth, bank risk increases. Vithessonthi (2014) found that the development of banking sector, also estimated by the growth in domestic credit to private sector, is positively related to bank risk, which can be hypothesized as follows:

H9: There is a positive relation between the bank sector development and bank risk.

Stock market development (SMD)

We use stock market development, measured as the ratio of stock market capitalization to GDP (in \%). The market cap variable represents the depth of stock markets and indicates the extent to which stock markets in a country are well developed. Vithessonthi (2014) suggested that increased stock market development will lead to a drop in capital to total risk-weighted assets, i.e. increasing bank risk. Hence, we hypothesize the following relationship:

H10: There is a positive relation between the stock market development and bank risk. 
Table 2 summarizes explanatory variables that are considered in the current study and their expected signs for bank risk.

\section{Table 2}

Explanatory variables

\begin{tabular}{|c|c|c|}
\hline Variable & Measurement & Expected sign \\
\hline $\begin{array}{l}\text { Bank asset structure } \\
\left(\text { Asset }_{i t}\right)\end{array}$ & Loan/ total assets & + \\
\hline Efficiency $\left(\mathrm{CIR}_{\mathrm{it}}\right)$ & Operating cost/ operating income & - \\
\hline Capitalization (Equity ${ }_{i t}$ ) & Equity/ total assets & - \\
\hline $\begin{array}{l}\text { Revenue diversification } \\
\left(\mathrm{RD}_{\mathrm{it}}\right)\end{array}$ & Ratio of non interest income to net revenue & + \\
\hline Bank size $\left(\right.$ Size $\left._{i t}\right)$ & Natural logarithm of total assets & - \\
\hline Profitability $\left(\mathrm{ROE}_{\mathrm{it}}\right)$ & After tax profit/Equity & - \\
\hline $\begin{array}{l}\text { Economic growth } \\
\left(\mathrm{GDP}_{\mathrm{it}}\right)\end{array}$ & Annual GDP growth rate & - \\
\hline Inflation $\left(\mathrm{INF}_{\mathrm{it}}\right)$ & Annual inflation rate & + \\
\hline $\begin{array}{l}\text { The bank sector } \\
\text { development (BSD) }\end{array}$ & $\begin{array}{l}\text { Ratio of domestic credit provided by } \\
\text { banking sector to GDP }\end{array}$ & + \\
\hline $\begin{array}{l}\text { The stock market } \\
\text { development (SMD) }\end{array}$ & Ratio of stock market capitalization to GDP & + \\
\hline
\end{tabular}

\section{Results}

\subsection{Determinants of bank risk}

Columns 1-3 of Table 3 report the results for the Eq. 1 using the three alternative proxies for bank risk with the system-GMM estimator suggested by Arellano and Bover (1995) and Blundell and Bond (1998). 


\section{Table 3}

Determinants of bank risk

\begin{tabular}{|c|c|c|c|}
\hline Variable & Z-score & Portrisk & Levrisk \\
\hline Z-score ${ }_{t-1}$ & $\begin{array}{c}0.848^{* * *} \\
(0.013)\end{array}$ & & \\
\hline Portrisk $_{\mathrm{t}-1}$ & & $\begin{array}{l}0.623^{* * *} \\
(0.029)\end{array}$ & \\
\hline Levrisk $_{\mathrm{t}-1}$ & & & $\begin{array}{l}0.809^{* * *} \\
(0.013)\end{array}$ \\
\hline Asset & $\begin{array}{l}0.623^{* * *} \\
(0.103)\end{array}$ & $\begin{array}{l}1.142^{* * *} \\
(0.179)\end{array}$ & $\begin{array}{l}0.362^{* * *} \\
(0.093)\end{array}$ \\
\hline CIR & $\begin{array}{l}-0.056^{*} \\
(0.029)\end{array}$ & $\begin{array}{l}-0.097 \\
(0.067)\end{array}$ & $\begin{array}{l}0.058^{* *} \\
(0.022)\end{array}$ \\
\hline Capitalization & $\begin{array}{l}1.896^{* * *} \\
(0.316)\end{array}$ & $\begin{array}{l}3.283^{\text {*** }} \\
(0.847)\end{array}$ & $\begin{array}{c}2.338^{* * *} \\
(0.180)\end{array}$ \\
\hline $\mathrm{RD}$ & $\begin{array}{c}-1.008^{* * *} \\
(0.220)\end{array}$ & $\begin{array}{c}-1.246^{* * *} \\
(0.264)\end{array}$ & $\begin{array}{l}-0.483^{* *} \\
(0.220)\end{array}$ \\
\hline SIZE & $\begin{array}{c}0.070^{* * *} \\
(0.012)\end{array}$ & $\begin{array}{c}0.089^{* * * *} \\
(0.016)\end{array}$ & $\begin{array}{c}0.091^{* * *} \\
(0.010)\end{array}$ \\
\hline ROE & $\begin{array}{l}-0.384 \\
(0.241)\end{array}$ & $\begin{array}{c}2.146^{* * * *} \\
(0.507)\end{array}$ & $\begin{array}{l}-0.147 \\
(0.195)\end{array}$ \\
\hline GDP & $\begin{array}{l}-0.129 \\
(0.241)\end{array}$ & $\begin{array}{c}-0.935^{* *} \\
(0.463)\end{array}$ & $\begin{array}{l}-0.086 \\
(0.189)\end{array}$ \\
\hline INF & $\begin{array}{l}-0.555 \\
(0.358)\end{array}$ & $\begin{array}{c}1.027 \\
(0.631)\end{array}$ & $\begin{array}{c}-1.373^{* * *} \\
(0.333)\end{array}$ \\
\hline BSD & $\begin{array}{c}-0.312^{* * *} \\
(0.073)\end{array}$ & $\begin{array}{c}-0.759^{* * *} \\
(0.093)\end{array}$ & $\begin{array}{c}-0.234^{* * *} \\
(0.046)\end{array}$ \\
\hline SMD & $\begin{array}{c}0.147^{* * *} \\
(0.025)\end{array}$ & $\begin{array}{c}0.362^{* * * *} \\
(0.037)\end{array}$ & $\begin{array}{c}0.057^{* * * *} \\
(0.020)\end{array}$ \\
\hline
\end{tabular}




\begin{tabular}{lccc}
\hline Variable & Z-score & Portrisk & Levrisk \\
\hline Constant & -0.195 & -1.297 & $-0.942^{* *}$ \\
\hline No. of Observations & $(0.445)$ & $(0.845)$ & $(0.426)$ \\
Test for AR(1) (p-value) & 364 & 360 & 408 \\
Test for AR(2) (p-value) & 0.000 & 0.002 & 0.000 \\
Hansen Test (p-value) & 0.908 & 0.194 & 0.111 \\
Country Dummies & 0.723 & 0.341 & 0.392 \\
\hline
\end{tabular}

Notes: Standard errors are reported in parentheses; ***,**, and * indicate significance at $1 \%, 5 \%$, and $10 \%$ levels respectively.

High significance levels of the lagged risk variables confirm the dynamic character of the model specification.

In the first column we find a negative relationship between the relative percentage of loans in the assets of a bank and its risk, which is in contrast with literature. Kohler (2012) stated that high rates of loan growth do not necessarily reflect excessive risktaking if all other banks have similarly high growth rates. If banks raise lending by lowering their lending standards, relaxing collateral requirements, or implementing a combination of both, higher rates of loan growth are associated with greater risk.

Efficiency is shown to increase bank risk as measured by the Z-score. Louzis et al. (2012) maintained that low cost efficiency is positively associated with increases in future NPLs. The proposed justification links 'bad' management with poor skills in credit scoring, appraisal of pledged collaterals, and monitoring borrowers.

We confirm our third hypothesis on the negative relationship between bank capitalization and risk. On the other hand, the revenue diversification has a positive relationship with bank risk, corroborating the fourth hypothesis that diversification does not reduce bank risk but in fact may encourage it.

Larger banks appear to be less risky, as indicated by their higher Z-scores, which confirms the fifth hypothesis. This could suggest that larger banks are more diversified and are likely to be more skilled in risk management, thus enabling them to deal more effectively with "bad" borrowers. 
We report a positive relationship between bank risk and the bank sector development, which is similar to Vithessonthi (2014), implying that banking sector development, on average, tends to lower bank capitalization ratios, and hence reduces financial soundness of banks.

Finally, the stock market development $(S M D)$ is shown to decrease bank risk as measured by the Z-score. That is, banks in more advanced financial markets become well capitalized, which would in turn enhance banking system stability (Vithessonthi, 2014). Profitability (ROE), economic growth $(G D P)$, and inflation $(I N F)$ are found not to be significant in our model.

\subsection{Robustness checks}

To verify the aforementioned findings, we consider two alternative measures of bank risk (Kohler, 2012):

$$
\begin{aligned}
& \text { Portfolio Risk }_{i t}=\frac{\text { ROA }_{i t}}{\operatorname{SDROA}_{i t}} \\
& \text { Leverage Risk }_{i t}=\frac{\text { CAR }_{i t}}{\operatorname{SDROA}_{i t}}
\end{aligned}
$$

The first component is the return on asset (ROA) of bank $i$ in year $t$ divided by the standard deviation of the return on asset (SDROA). It can be thought of as bank's riskadjusted return and in this sense interpreted as a measure of portfolio risk. The second one is each bank's ratio of bank's equity to total assets $(C A R)$ divided by SDROA. It reflects bank's leverage risk. In both cases higher values indicate that banks are more stable. The results with our two alternative indicators of bank risk are presented in the first and second columns of Table 3 .

The first of these metrics, portfolio risk ( Portrisk $_{i t}$ ), yields expected signs and significance that are similar to those of our original model, except for the significance of economic growth $(G D P)$. As a priori, we would expect bank risk to be lower since unemployment and insolvency rates should be lower in an economic upswing. However, we find that it increases the level of portfolio risk. This suggests that banks may also face more risk if they reduce their screening activity and lending standards during expansions.

Finally, we employ the leverage risk (Levrisk $k_{i t}$ ) to represent bank risk. The results obtained from the leverage risk mostly agree with those for our original model, except 
for the strong significance of inflation $(I N F)$. This result may reflect the fact that higher inflation increases bank risk in Southeast Asian countries.

\section{Conclusions and policy implications}

In this study we use system-GMM estimator to examine the determinants of bank risk in the Southeast Asian banking sector. We examine both bank-specific and macroeconomic determinants of bank risk, analyzing ten variables that have been proven to impact on it. These comprise asset structure, efficiency, capitalization, revenue diversification, size, profitability, economic growth, inflation, the banking system development, and the stock market development. We proxy bank risk using the Z-score, which is an overall measure of its, including both liquidity risk and market risk.

We find that bank-specific variables such as asset structure, capitalization, and size are negatively and significantly related to bank risk, whereas efficiency and revenue diversification are positively related to bank risk. Macroeconomic variables, specifically in the further banking system development, are found to increase bank risk, while the more the stock market grows, the lower the level of bank risk.

We apply robustness checks by considering two alternative measures of bank risk: portfolio risk and leverage risk. The results of these tests yield signs and significance levels similar to those in the original model for most of the independent variables, thus proving their robustness.

These findings have a few policy implications for the banking system in Vietnam. First, commercial banks in Vietnam need to enhance financial capability in terms of their own equity, asset quality, and size to decrease bank risk. Second, bank efficiency is positively related to bank risk. According to the skimping hypothesis as stated in Louzis et al. (2012), there is a trade-off between resource allocation in lending and loan surveillance and cost reduction. This implies that if banks cut costs related to the assurance of credit quality, the bad debt ratio is more likely to increase in the long run. Hence, it is necessary for them to consider essential and appropriate cost cutting so as not to affect credit risk management. Finally, policymakers should seek to strengthen the appropriate type and quality of financial development rather than expand the financial sector (the banking system).

The study can be extended in future research. First, it would be useful to examine other countries which have the same characteristics as Southeast Asian ones to 
generalize the empirical results. Second, it may be worth elaborating on the study of bank risk determinants by using alternative statistical tools such as structural equation modeling

\section{Notes}

${ }^{1}$ As alternative indicators of bank risk, we later also consider the two components of Z-score which measure banks' exposure to portfolio and leverage risk.

${ }^{2}$ Due to space constrainst, we only report the VIF test in which Z-score is employed as the dependent variable. The values for the test in which Portrisk and Levrisk are dependent variables are available upon request.

${ }^{3} \mathrm{AR}(1)$ and $\mathrm{AR}(2)$ are tests for first- and second-order serial correlation in the first-differenced residuals, under the null of no serial correlation respectively.

${ }^{4}$ Hansen test of over-identification is under the null that all instruments are valid.

${ }^{5}$ Country dummies used here are instruments for System GMM as stated in the methodology session. Country dummies are also for controlling country-specific factors other than INF, GDP, BSD, and SMD that can affect bank risk-taking behavior.

\section{References}

Altunbas, Y., Manganelli, S., \& Marques-Ibañez, D. (2011). Bank risk during the financial crisis: Do business models matter (Working Paper Series No 1394)? Frankfurt, Germany: European Central Bank.

Arellano, M., \& Bover, O. (1995). Another look at the instrumental variable estimation of errorcomponents models. Journal of Econometrics, 68(1), 29-51.

Baselga-Pascual, L., Trujillo-Ponce, A., \& Cardone-Riportella, C. (2015). Factors influencing bank risk in Europe: Evidence from the financial crisis. North American Journal of Economics and Finance, 34(2015), 138-166.

Blundell, R., \& Bond, S. (1998). Initial conditions and moment restrictions in dynamic panel data models. Journal of Econometrics, 87(1), 115-143.

Cubillas, E., \& González, F. (2014). Financial liberalization and bank risk-taking: International evidence. Journal of Financial Stability, 11, 32-48.

Demirgüc-Kunt, A., \& Huizinga, H. (2010). Bank activity and funding strategies: The impact on risk and returns. Journal of Financial Economics, 98(3), 626-650.

Kohler, M. (2012). Which banks are more risky? The impact of loan growth and business model on bank risk-taking (Discussion Paper No 33/2012). Frankfurt, Germany: Deutsche Bundesbank.

Laeven, L., \& Levine, R. (2009). Bank governance, regulation and risk taking. Journal of Financial Economics, 93(2), 259-275. 
Louzis, P., Vouldis, A. T., \& Metaxas, V. L. (2012). Macroeconomic and bank-specific determinants of non-performing loans in Greece: A comparative study of mortgage, business and consumer loan portfolios. Journal of Banking \& Finance, 36(4), 1012-1102.

Männasoo, K., \& Mayes, D. G. (2009). Explaining bank distress in Eastern Europeantransition economies. Journal of Banking and Finance, 33(2), 244-225.

Mercieca, S., Schaeck, K., \& Wolfe, S. (2007). Small European banks: Benefits from diversification? Journal of Banking and Finance, 31(7), 1975-1998.

Poghosyan, T., \& Čihak, M. (2011). Determinants of bank distress in Europe: Evidence from a new data set. Journal of Financial Services Research, 40(3), 163-184.

Ruiz-Porras, A. (2009). Financial structure, financial development and banking fragility: International evidence. Análisis Económico, XXIV(56), 147-173.

Stiroh, K. (2002). Diversification in banking: Is noninterest income the answer (FRB of New York Staff Report No. 154)? NY: Federal Reserve Bank of New York.

Uhde, A., \& Heimeshoff, U. (2009). Consolidation in banking and financial stability in Europe: Empirical evidence. Journal of Banking and Finance, 33(7), 1299-1311. doi:10.1016/j.jbankfin.2009.01.006

Vithessonthi, C. (2014). The effect of financial markets development on bank risk: Evidence from Southeast Asian Countries. International Review of Financial Analysis, 35(2014), 249-260.

Williams, B. (2014). Bank risk and national governance in Asia. Journal of Banking \& Finance, 49 , $10-26$.

Windmeijer, F. (2005). A finite sample correction for the variance of linear efficient two-step GMM estimators. Journal of Econometrics, 126(1), 25-51. 